\title{
P01.16. A root extract of Helleborus niger possess cytotoxic properties in neuroblastoma cells
}

\author{
C Delebinski, G Kauczor, P Jesse, K Seeger, G Henze, G Seifert \\ From International Research Congress on Integrative Medicine and Health 2012 \\ Portland, Oregon, USA. 15-18 May 2012
}

\section{Purpose}

Helleborus niger (Ranunculaceae), commonly known as Christmas rose, is used in anthroposophically extended cancer therapy in the adjuvant treatment of different entities and reduction of chemotherapy-associated side effects. Although Helleborus niger is widely used in anthroposophic medicine, there is a lack of scientific clinical and preclinical data and until now it is applied on an empirical basis. Neuroblastoma is one of the most common extracranial solid tumors of childhood, and more than $50 \%$ of these children initially present with nonresectable primary tumors and disseminated metastasis to distant organ sites, predominantly bone marrow. In this study, we determined for the first time the cytotoxic properties of Helleborus niger Root (HNR) extract for neuroblastoma in vitro.

\section{Methods}

The cytotoxic effect of HNR on the neuroblastoma cell line NXS2 was determined using LDH-assay, mitochondrial membrane potential measurement and Annexin/PI assays. The mechanism of apoptosis was further analyzed by Western blot analysis, caspase inhibitors and mitochondria membrane isolation in more detail.

\section{Results}

We could show that HNR is able to inhibit cell proliferation in a time and concentration dependent manner in NXS2 cells. Furthermore, Annexin/PI and JC-1 assays indicated a dose-dependent induction of apoptosis as the main mechanism of cell death. While western blot analysis revealed a caspase- 8 and -9 involvement of apoptosis induction, the incubation with caspase inhibitors did not prevent apoptosis. Moreover, we could

Submit your next manuscript to BioMed Central and take full advantage of:

- Convenient online submission

- Thorough peer review

- No space constraints or color figure charges

- Immediate publication on acceptance

- Inclusion in PubMed, CAS, Scopus and Google Scholar

- Research which is freely available for redistribution 